\title{
Impact of rock mass temperature on potential power and electricity generation in the ORC installation
}

\author{
Michat Kaczmarczyk ${ }^{1 *}$ \\ ${ }^{1}$ AGH University of Science and Technology, 30-059 Krakow, Poland
}

\begin{abstract}
The basic source of information for determining the temperature distribution in the rock mass and thus the potential for thermal energy contained in geothermal water conversion to electricity, are: temperature measurements in stable geothermic conditions, temperature measurements in unstable conditions, measurements of maximum temperatures at the bottom of the well. Incorrect temperature estimation can lead to errors during thermodynamic parameters calculation and consequently economic viability of the project. The analysis was performed for the geothermal water temperature range of $86-100^{\circ} \mathrm{C}$, for dry working fluid R245fa. As a result of the calculations, the data indicate an increase in geothermal power as the geothermal water temperature increases. At $86^{\circ} \mathrm{C}$, the potential power is $817.48 \mathrm{~kW}$, increases to 912.20 $\mathrm{kW}$ at $88^{\circ} \mathrm{C}$ and consequently to $1493.34 \mathrm{~kW}$ at $100^{\circ} \mathrm{C}$. These results are not surprising, but show a scale of error in assessing the potential that can result improper interpretation of the rock mass and geothermal waters temperature.
\end{abstract}

\section{Introduction}

Research of deep geothermal systems requires careful analysis of a number of key geological factors, where the quality of the data determining the reliability of the models [13]. In the case of thermodynamic analysis of heat accumulated in geothermal waters utilization [4-5], ex. using Organic Rankine Cycle (ORC), one of the key parameters is the temperature of geothermal waters determined by the thermal parameters of the rock mass. This is crucial in the context of correct estimation of power, efficiency and quantity of electricity. Even a slight error of several Celsius degrees, can result in the underestimation or overestimation of potential that can be possible use and leads into an incorrect economic assessment of the planned installation. Therefore, it is important to interpret accurately the thermal data of the rock mass. The paper presents the consequences of incorrect determination of the temperature of geothermal waters used in the ORC systems.

\footnotetext{
*Corresponding author: $\underline{\text { mkz@agh.edu.pl }}$
} 


\section{Temperature data}

The primary source of information in the case of in-depth temperature -distribution, and hence the potential for conversion of heat accumulated in geothermal waters into electricity are temperature measurements in stable geothermic conditions, temperature measurements in unstable conditions, and maximum temperature measurements at the bottom of the borehole [6].

From the point of view of correct determination of geothermal waters temperature, the measurement in stable conditions (thermal equilibrium) are crucial. In the case of measurement in unstable conditions, we have to deal with disrupted temperature distribution which results from the drilling process, mainly from the long-term drilling fluid circulation [6-7]. It causes growth of the temperature in the shallower zone of the borehole and its lowering at the bottom of the borehole, which in consequence leads to incorrect interpretation of the temperature log. According to Plewa [8], it is possible to assume that the minimum time to reach thermal equilibrium after drilling is finished is 7 days for boreholes with depth up to $1500 \mathrm{~m}$, and 12-14 days for boreholes up to $3000 \mathrm{~m}$ deep. Because the circulation of the drilling fluid is the shortest in the deepest borehole interval, the data from the maximum temperature measurements on the bottom of the borehole can also be useful [6]. The above also leads to the conclusion that in the thermal profile there is an interval in which the temperature corresponds to the real values (Figure 1), but it is impossible to determine that zone [6].

A different issue is the impact of paleoclimatic changes on which detailed information can be found in publications [7, 9-11].

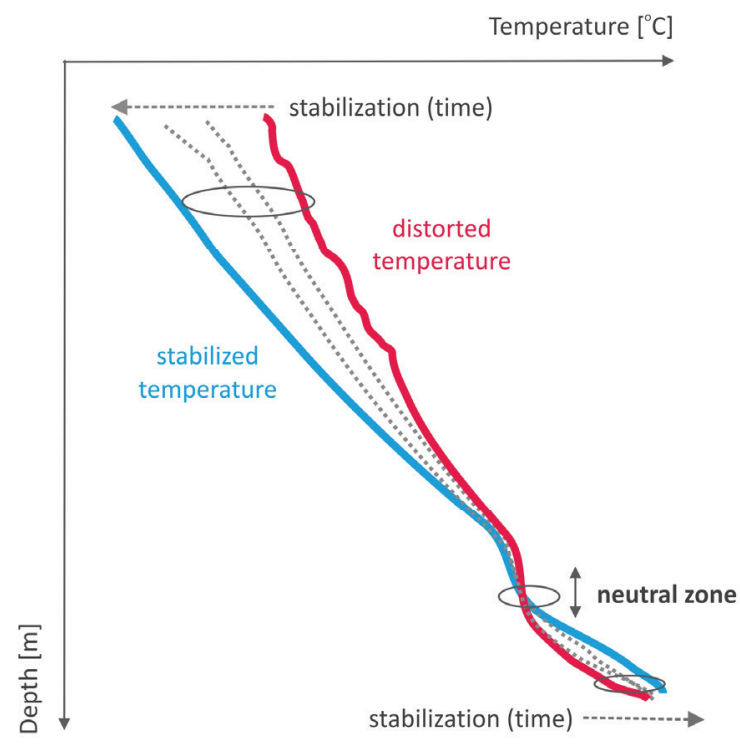

Fig. 1. Temperature changes caused by disturbances of thermal equilibrium in wells (based on [6]).

The use of temperature data measure in unstable conditions can lead to errors in estimating the power and efficiency of geothermal power plants, and consequently to the errors in the key economic cost of the project to be implemented from the investor's point of view. 


\section{Estimation of potential power and conversion efficiency of heat into electricity in ORC geothermal power plants}

\subsection{Technology of conversion heat into electricity}

The technology of converting electricity using geothermal energy depends on the thermal and hydrogeological conditions prevailing in the area. This specificity has led to the emergence of a variety of technologies that allow the generation of electricity based on geothermal resources.

The use of organic working fluid is the most common method of producing electricity using geothermal waters with the temperature not exciding $100^{\circ} \mathrm{C}$ [12] and hot dry rocks reservoir [13]. Properly selected working fluid has boiling temperature lower than geothermal water temperature, at a pressure higher than the ambient pressure. It works according to the Clausius-Rankine comparative cycle [14].

A typical work cycle performed by geothermal water and the working fluid at the ORC power plant is shown on Figure 2. The geothermal water extracted through the production well is directed by particle filter to the heat exchanger system: superheater-evaporatorpreheater, which transfers heat accumulated in geothermal water into the working fluid and evaporate it. After that the working fluid is moved as a steam to the turbogenerator, whereby by changing the potential energy accumulated in the working fluid into mechanical energy of the turbine blades rotation, electricity is produced. The next step is directed the working fluid vapor to the condenser and liquefy it to the original state (liquid), which is the closure of the cycle. Condensation is possible by directing to the condenser cooling water, which receiving heat from the working fluid. For this process to be carried out, an open cooling circuit such as surface water, or alternatively a cooling tower, is used.

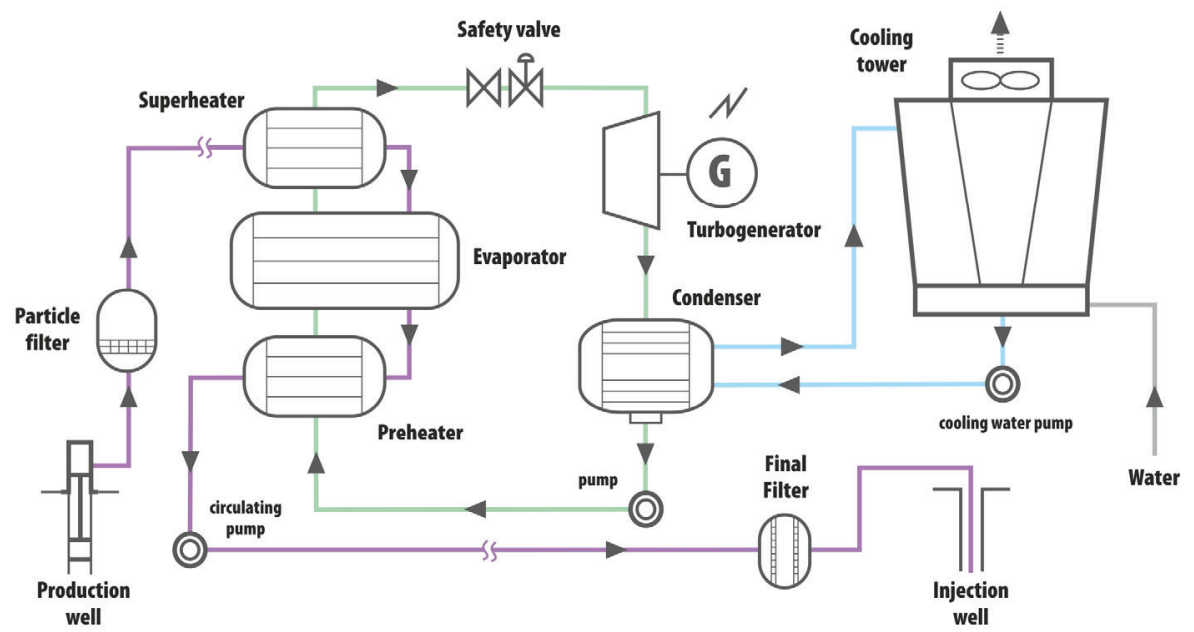

Fig. 2. A schematic diagram of an ORC plant (based on [12]).

\subsection{Geothermal water as a determinant of efficiency and power}

The main factors influencing the thermal efficiency and power of a geothermal power plant are: geothermal water temperature at outflow, geothermal water flow rate, physicochemical properties of geothermal water, type of technology used, condensation 
temperature and cooling system used. At the same time, the temperature of the geothermal water supplying the geothermal power plant is crucial for both its power and efficiency, which leads to the conclusion that these parameters increase with increasing geothermal water temperature. Rock mass temperature, and hence geothermal water temperature, are determined by the density of the Earth's heat flux and by the thermal properties of the rocks (thermal conductivity, specific heat) in the studied lithological profile. It can be determined primarily on the basis of a detailed analysis of drilling data, which the geological structures have been drilled and identified.

\section{Assumptions and methodology of performing thermodynamic calculations}

The analysis was performed for the geothermal water temperature range from $86^{\circ} \mathrm{C}$ to $100^{\circ} \mathrm{C}$, changing the temperature range every $2^{\circ} \mathrm{C}$. This range is due to the temperature of geothermal waters available for use in Poland. In the presented studies on the potential of geothermal systems based on ORC, dry working fluid R245fa was analyzed, which according to previous analyzes by the author [15], allows to obtain the highest efficiency and power of the ORC geothermal power plant. For the calculations author developed the thermodynamic model, with the values of temperature, pressure, enthalpy and entropy at specific points determined using the NIST REFPROP 9.1 database. This is a program developed by the National Institute of Standards and Technology for the analysis of thermodynamic processes [15].

For the calculation model, it was assumed that the Organic Rankine Cycle consists of a turbine (connected to a generator), a condenser (connected to a cooling tower), a feed pump, a preheater, an evaporator and a superheater (Figure 3). The power of a geothermal power plant can be described in accordance with the first principle of thermodynamics $[12,17]$ :

$$
W_{\text {gross }}=Q_{d} \cdot \eta_{O R C}=m_{w f} \bullet\left(h_{w f 1}-h_{w f 4}\right) \cdot \eta_{O R C}
$$

where:

$\mathrm{W}_{\text {gross }}$ - power [W]

$\mathrm{Q}_{\mathrm{d}}-$ heat flux supplied to the superheater, evaporator and preheater [W]

ПORC - thermal efficiency [-]

$\mathrm{m}_{\mathrm{wf}}-$ mass flow of the working fluid $[\mathrm{kg} / \mathrm{s}]$

$\mathrm{h}_{\mathrm{wf} 1}, \mathrm{~h}_{\mathrm{wf} 4}-$ specific enthalpy $[\mathrm{kJ} / \mathrm{kg}]$

The amount of gross electricity was calculated from the power plant capacity and the working time. Based on the analysis of the data contained in the "Atlas ..." [18], it was assumed that the plant's operating time would be 4000 hours:

$$
E_{\text {el }}=W_{\text {gross }} \bullet t
$$

where:

$\mathrm{E}_{\mathrm{el}}-$ electricity $[\mathrm{Wh}]$

$\mathrm{W}_{\text {gros }}-$ power $[\mathrm{W}]$

$\mathrm{t}$ - operation time $[\mathrm{h}]$

The obtained results refer to the gross power and the gross electricity output. The methodology of calculations was adopted from $[12,16,18]$.

For calculations the values corresponding to geothermal water from the borehole of the Bańska PGP-1 were assumed. The flow rate of the production well was taken as the maximum value $550 \mathrm{~m}^{3} / \mathrm{h}$. It was assumed that the temperature of the geothermal water leaving the geothermal power plant would be $60^{\circ} \mathrm{C}$. The working fluid condensation 
temperature was assumed as a constant value of $30^{\circ} \mathrm{C}$, as well as the overheating temperature of the operating medium $\mathrm{T}_{\mathrm{s}}=3^{\circ} \mathrm{C}$. The mineralization of geothermal water was assumed to be a constant value of $3.12 \mathrm{~g} / \mathrm{dm}^{3}$. Due to the influence of geothermal water temperature parameter, the values of the geothermal water density have been estimated based on the methodology given in [19-20] in a variable temperature range of $86-100^{\circ} \mathrm{C}$. This is one of factors which determine the conditions in which geothermal waters are used, especially the amount of energy obtained and the manner in which cooled water is utilized [5].

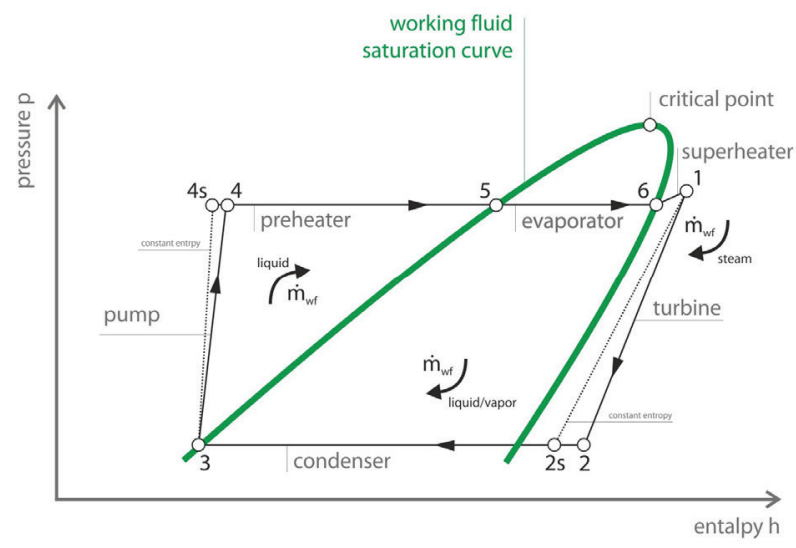

Fig. 3. Pressure enthalpy diagram with applied specific points; Explanation: 1-2s - isentropic expansion of the working fluid in the turbine, $2-2 \mathrm{~s}-$ cooling of the working fluid in the condenser, $2 s-3-$ condensation of the working fluid in the condenser, $3-4 s-$ isentropic pumping of the working fluid by the feed pump, 5 - heating of the working fluid in the preheater, 5-6-evaporating of the working fluid in the evaporator, 6-1 - superheating of the working medium in the superheater (based on [12]).

\section{Results and analysis}

The calculations show that the geothermal water temperature is crucial for the thermal efficiency and power output. From the point of view of proper assessment of the rock parameters, a correct assessment of thermal parameters should be a priority, as having a direct impact on the estimation of the potential use of energy accumulated in geothermal waters for electricity purposes. The data compiled in Table 1 and on Figures 3 and 4 show the significant increase in geothermal power as the geothermal water temperature increases. At $86^{\circ} \mathrm{C}$, the potential gross power is $817.48 \mathrm{~kW}$, increases to $912.20 \mathrm{~kW}$ at $88^{\circ} \mathrm{C}$ and consequently to $1493.34 \mathrm{~kW}$ at $100^{\circ} \mathrm{C}$. These results are not surprising, but show a scale of possible error in assessing the potential that can result improper interpretation of the rock mass temperature. Similar as with power, efficiency also increases from $6 \%$ (at $86^{\circ} \mathrm{C}$ ) to $8 \%$ at $100^{\circ} \mathrm{C}$. Power and efficiency determine the amount of electricity that increases from $3269.92 \mathrm{MWh}$ to $5973.34 \mathrm{MWh}$ in the studied temperature range $86-100^{\circ} \mathrm{C}$.

The data show that in case of an error in estimating the temperature of geothermal waters we are dealing with overestimation or underestimation of potential capacity and electricity of geothermal power plant by c.a. $11 \%$ for every $+/-2^{\circ} \mathrm{C}$. It should be emphasized that this type of error results in the selection of individual components of the plant, such as the size of the turbine, heat exchangers or the power of the feed pump, and thus the optimization of the system so that it operates at optimum performance using the full potential of the geothermal resource. 
Table 1. Results of thermodynamic calculations.

\begin{tabular}{|c|c|c|c|c|c|}
\hline Temperature & $\begin{array}{c}\text { Geothermal } \\
\text { water density }\end{array}$ & Power & Electricity & Efficeincy & $\begin{array}{c}\text { Turbine / feed } \\
\text { pump power }\end{array}$ \\
\hline${ }^{\circ} \mathrm{C}$ & $\mathrm{kg} / \mathrm{m}^{3}$ & $\mathrm{~kW}$ & $\mathrm{MWh}$ & - & $\mathrm{kW}$ \\
\hline 86 & 990,8162 & 817,48 & 3269,92 & 0,06 & $1044,01 / 23,23$ \\
\hline 88 & 989,5068 & 912,20 & 3648,78 & 0,07 & $1183,06 / 26,88$ \\
\hline 90 & 988,1806 & 1007,78 & 4031,10 & 0,07 & $1327,48 / 30,77$ \\
\hline 92 & 986,838 & 1103,57 & 4414,29 & 0,07 & $1477,58 / 36.06$ \\
\hline 94 & 985,4792 & 1200,02 & 4800,07 & 0,07 & $1632,11 / 40,47$ \\
\hline 96 & 984,1043 & 1298,15 & 5192,62 & 0,08 & $1793,73 / 45,10$ \\
\hline 98 & 982,7136 & 1396,34 & 5585,36 & 0,08 & $1961,59 / 51,29$ \\
\hline 100 & 981,3072 & 1493,34 & 5973,34 & 0,08 & $2133,04 / 57,82$ \\
\hline
\end{tabular}

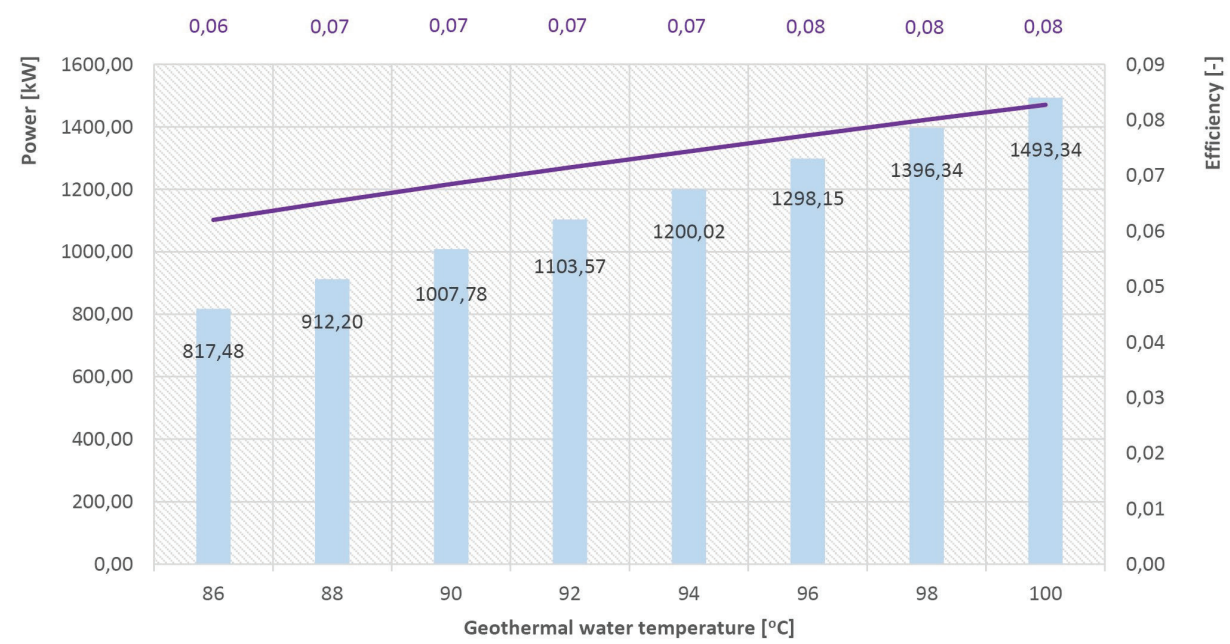

Fig. 3. The results of the thermodynamic calculations for the obtained power and efficiency.

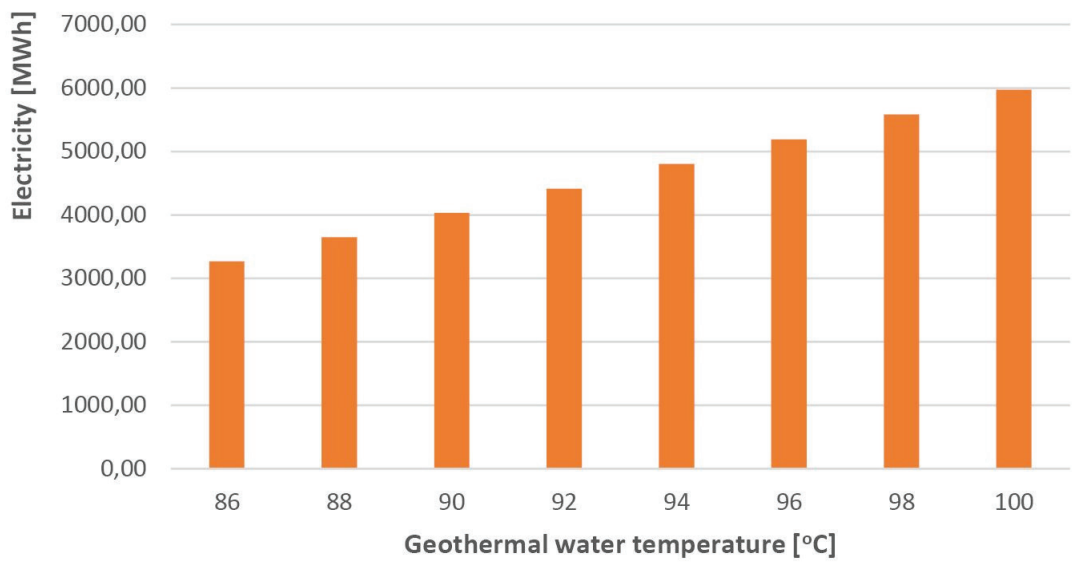

Fig. 4. The amount of gross electricity depends on the geothermal water temperature. 


\section{Conclusions}

1. Research of deep geothermal systems requires careful analysis of a number of key geological factors, especially temperature which has great impact on the potential power, efficiency and amount of electricity in ORC power plant.

2. From the point of view of correct determination of geothermal waters temperature, the measurement in stable conditions (state of geothermic equilibrium) are crucial. The use of temperature data measure in unstable conditions will lead to errors in estimating the power and efficiency of geothermal power plants, and consequently to the errors in the key economic cost of the implemented project from the investor's point of view.

3. Making an error in estimating the temperature of geothermal waters we are dealing with overestimation or underestimation of of potential capacity and electricity of geothermal power plant by c.a. $11 \%$ for every $+/-2^{\circ} \mathrm{C}$.

\section{References}

1 W. Bujakowski, B. Tomaszewska, M. Miecznik, Renew. Energy 99, 420-430 (2016) doi 0.1016/j.renene.2016.07.028

2 M. Pussak, K. Bauer, M. Stiller, W. Bujakowski, J. Appl. Geophys. 103, 186-198 (2015) doi 10.1016/j.jappgeo.2014.01.020

3 B. Tomaszewska, L. Pająk, G. Hołojuch, Desalin. Water Treat. 69, 316-321 (2017) doi: $10.5004 /$ dwt.2017.0657

4 B. Tomaszewska, L. Pająk, Gospod. Surowcami Min. 4, 59-70 (2012) doi: 10.2478/v10269-012-0038-7

5 B. Tomaszewska, L. Pająk, Using treated geothermal water to replenish network water losses in a district heating system, Pol. J. Environ Stud., 22, 1, 243-250 (2013)

6 J. Szewczyk, M. Hajto, Strumień cieplny a temperatury wgłębne na obszarze Niżu Polskiego [in.] W. Górecki [ed.], Atlas zasobów geotermalnych formacji mezozoicznej na Niżu Polskim (Kraków 2006)

7 J. Szewczyk, Estymacja gęstości strumienia cieplnego metoda modelowań właściwości termicznych ośrodka, Przegląd Geologiczny 49, 11 (2001)

8 S. Plewa, Rozkład parametrów geotermalnych na obszarze Polski (Wydawnictwo CPPGSMiE PAN, Kraków 1994)

9 J. Majorowicz, J. Safanda, R. Przybylak, G. Wójcik, Rekonstrukcja zmian temperatury powierzchni gruntu $w$ Polsce $w$ ostatnim 500-leciu na podstawie profili geotermicznych, Przegląd Geologiczny 4 (2001)

10 J. Majorowicz, M. Wróblewska, P. Krzywiec, Interpretacja i modelowanie ziemskiego strumienia cieplnego $w$ obszarze eksperymentu sejsmicznego POLONAISE'97 analiza krytyczna, Przegląd Geologiczny 50, 11 (2002)

11 J. Szewczyk, Ślady zmian klimatycznych plejstocenu oraz holocenu $w$ profilach temperatury $w$ głębokich otworach wiertniczych na Niżu Polskim, Przegląd Geologiczny 50, 11 (2002)

12 R. DiPippo, Geothermal Power Plants: principles, applications, case studies and environmental impact (Library of Congress Cataloging-in-Publication Data, Elsevier Ltd. 2012)

13 W. Bujakowski, M. Miecznik, L. Pająk, R. Skrzypczak, A. Sowiżdżał, Renew. Energy 80, 441-453 (2015) doi.org/10.1016/j.renene.2015.02.018 
14 A. Borsukiewicz-Gozdur, W. Nowak, A.A. Stachel, Systemy do generacji prąu elektrycznego przy wykorzystaniu wód geotermalnych - perspektywy rozwoju w Polsce, Materiały Ogólnopolskiego Kongresu Geotermalnego, Radziejowice (2007)

15 M. Kaczmarczyk, Analiza i ocena możliwości produkcji energii elektrycznej przy wykorzystaniu energii cieplnej zakumulowanej $w$ wodach geotermalnych na obszarze województwa małopolskiego, rozprawa doktorska (AGH WGGiOŚ KSE, Kraków 2016)

16 A. Borsukiewicz-Gozdur, W. Nowak, Desirable Thermophysical Properties of Working Fluids In Organic Rankine Cycle, Proceedings European Geothermal Congress (Unterhaching, Germany 2007)

17 E.W. Lemmon, M.L. Huber, M.O. McLinden, NIST Reference Fluid Thermodynamic and Transport Properties - REFPROP, Version 9.1, User's Guide, U.S. Department of Commerce, Technology Administration, (National Institute of Standards and Technology, Standard Reference Data Program 2013)

18 W. Bujakowski W., B. Tomaszewska [eds.], Atlas wykorzystania wód termalnych do skojarzonej produkcji energii elektrycznej $i$ cieplnej przy zastosowaniu układów binarnych $w$ Polsce (IGSMiE PAN, Kraków 2014)

19 M. H. Sharqawy, V. J. H. Lienhard, S. M. Zubair, Desalin. Water Treat. 16, 354-380 (2010) doi 10.5004/dwt.2010.1079

20 M. Miecznik, Błąd szacowania potencjatu dla wytwarzania energii elektrycznej $w$ instalacjach binarnych typu ORC zwiazany ze zmiennościa parametrów termodynamicznych wody geotermalnej, Technika Poszukiwać Geologicznych Geotermia, Zrównoważony Rozwój 2, 155-166 (2013) 